\title{
Multiyear Regional Evaluation of Foliar Fungicide Applications for Cotton Target Spot Management in the Southeastern United States
}

\author{
H. L. Mehl, ${ }^{1,}{ }^{\dagger}$ N. S. Dufault, ${ }^{2}$ T. W. Allen, ${ }^{3}$ A. K. Hagan, ${ }^{4}$ P. Price, ${ }^{5}$ R. C. Kemerait, ${ }^{6}$ H. Kelly, ${ }^{7}$ M. J. Mulvaney, ${ }^{8}$ and R. L. Nichols ${ }^{9}$ \\ ${ }^{1}$ Virginia Tech Tidewater Agricultural Research and Extension Center, Suffolk, VA 23437 \\ ${ }^{2}$ Department of Plant Pathology, University of Florida, Gainesville, FL 32611 \\ ${ }^{3}$ Mississippi State University, Delta Research and Extension Center, Stoneville, MS 38776 \\ ${ }^{4}$ Department of Entomology and Plant Pathology, Auburn University, AL 36849 \\ ${ }^{5}$ Macon Ridge Research Station, Louisiana State University Agricultural Center, Winnsboro, LA 71295 \\ ${ }^{6}$ Department of Plant Pathology, University of Georgia, Tifton, GA 31793 \\ ${ }^{7}$ Department of Entomology and Plant Pathology, The University of Tennessee, Jackson, TN 37996 \\ ${ }^{8}$ Agronomy Department, University of Florida, Institute of Food and Agricultural Sciences, Jay, FL 32565 \\ ${ }^{9}$ Cotton Incorporated, Cary, NC 27513
}

\begin{abstract}
Fungicide programs for managing target spot of cotton caused by Corynespora cassiicola were evaluated over 15 site-years in the southeastern United States between 2014 and 2016. Two cultivars, hypothesized to vary in target spot susceptibility, PhytoGen 499WRF (PHY499) and Deltapine 1137B2RF (DPL1137), and four fungicides (azoxystrobin, flutriafol, pyraclostrobin, pyraclostrobin + fluxapyroxad) plus nontreated control, were compared. Fungicide programs consisted of 1) a single application at first flower or disease onset and 2) the first application followed by a second 14 days later. Treatments were applied in a facto-

Fungicides delayed disease development and defoliation, but application number had little impact. Based on a meta-analysis of 15 site-years, pyraclostrobin-based applications resulted in a 4 to $6 \%$ yield preservation, and yield preservation was greater at site-years with early disease onset and $>40 \%$ target spot associated defoliation. Results suggest a single well-timed application of a pyraclostrobin-based fungicide reduces defoliation and protects cotton yield at locations with high target spot severity. Additional research is needed to identify risk factors for target spot-associated yield losses in cotton production systems.
\end{abstract} rial, randomized complete block design. Target spot onset and severity varied among site-years. Except when severity was low, target spot-associated defoliation was greater on PHY499 than on DP1137.
Keywords: fungi, field crops, disease management, chemical, yield loss and economic impacts, Corynespora cassiicola, Gossypium hirsutum
Corynespora leaf spot, or target spot, of cotton (Gossypium hirsutum L.), caused by Corynespora cassiicola (Berk. \& M.A. Curtis) C.T. Wei, has until recently been considered a minor foliar disease (Sumabat et al. 2018a). However, recent reports indicate target spot is emerging as a disease of increased importance in the southeastern U.S. cotton production system. Target spot was first described as a cotton disease in samples collected from Mississippi in 1959 (Jones 1961), but widespread disease incidence in cotton was not reported until 2008 in Georgia (Fulmer et al. 2012). Previously, C. cassiicola was considered a soybean (Glycine max (L.) Merr.) and tomato (Solanum lycopersicum L.) pathogen in the southeastern United States (Koenning et al. 2006; Pernezny et al. 2002). However, since 2012, C. cassiicola has been reported on cotton throughout the southeastern and south-central United States including Alabama (Conner et al. 2013), Arkansas (Faske 2013), Florida (Sumabat et al. 2018a), Louisiana (Price et al. 2015), Mississippi (Schultz et al. 2017), North Carolina (Edmisten 2012), Tennessee (Butler et al. 2016), and Virginia (Mehl

${ }^{\dagger}$ Corresponding author: H. L. Mehl; hlmehl@vt.edu

H. L. Mehl and N. S. Dufault share first authorship.

Funding: Funding for this project was provided by Cotton Incorporated. Additional support was provided by USDA National Institute of Food and Agriculture Hatch project FLA-JAY-005475.

*The $\boldsymbol{e}$-Xtra logo stands for "electronic extra" and indicates that one supplementary table is published online.

The author(s) declare no conflict of interest.

Accepted for publication 20 August 2019.

(C) 2020 The American Phytopathological Society and Phipps 2013). In addition to target spot observations throughout the southern United States, the disease has recently been reported in cotton from Brazil and China, indicating a greater, worldwide distribution of the disease (Galbieri et al. 2014; Wei et al. 2014).

Target spot symptoms are distinctive, and lesions that result from C. cassiicola infection are generally observed on leaves in the lowerto-middle canopy. Lesions in the lower canopy initially appear following canopy closure, which often coincides with cotton plants entering the reproductive stage (first flower). Mature lesions are round with alternating dark and light brown concentric rings; hence the preferred name for the disease is target spot in most areas (Hagan et al. 2017; Price et al. 2015). In some cases, lesions are surrounded by a yellow halo, but this symptom does not always occur and may be related to host plant genetics or other advantageous pathogens (personal observation). In addition, lesions resulting from $C$. cassiicola infection can develop on other cotton plant parts (e.g., bolls, bracts, petioles, stems) but may not exhibit concentric rings and can vary in size depending on location within the canopy (personal observation).

Moderate temperatures $\left(25\right.$ to $30^{\circ} \mathrm{C}$ ) and high humidity with prolonged periods of leaf wetness favor disease development (Bowen et al. 2018; Hagan et al. 2017; Jones and Jones 1984; Sharma 2017). Certain cotton management practices may also favor target spot development. Rank vegetative growth that results from excessive nitrogen fertilization and/or a lack of canopy management with growth regulators can create a humid microclimate within the plant canopy, thus favoring infection and dispersal of the pathogen. Leaves exhibiting multiple target spot lesions typically abscise, leading to early defoliation (Conner et al. 2013). Rapid defoliation progressing from the lower to upper canopy can occur during extended periods of conducive environmental conditions (Bowen et al. 2018; Hagan et al. 2017, 2018).

Even though cotton yield losses due to target spot have been difficult to quantify, premature defoliation may impact cotton lint yield if leaves subtending developing bolls are lost at early stages of boll 
development. In severe cases, premature defoliation greater than $70 \%$ has been reported from fields in Alabama, Georgia, and Louisiana (Bowen et al. 2018; Fulmer et al. 2012; Price et al. 2015). Yield losses are related to timing of infection and subsequent defoliation relative to cotton stage of development. Target spot causes premature defoliation in contrast to other common cotton foliar diseases such as those caused by Alternaria macrospora A. Zimmerm., Cercospora gossypina Cooke, and Stemphylium solani G.F. Weber, which do not typically result in premature defoliation and rarely impact cotton yield (Hillocks 1992; Kirkpatrick and Rothrock 2001). The leaf spot diseases aside from target spot usually have minimal impacts on yield, are not economically managed through the use of foliar fungicides, and tend to be associated with drought and potassium deficiency (Harris 1997; Hillocks and Chinodya 1989; Woodward et al. 2016). In contrast, target spot is a disease of vigorous, wellfertilized cotton with high yield potential.

Over the past decade, target spot has become a perceived threat to cotton production in the southeastern United States, increasing the need for effective management strategies to minimize concerns about potential yield losses (Bell 1999; Hillocks 1992; Kirkpatrick and Rothrock 2001). A combination of disease resistant/tolerant cultivars and well-timed fungicide applications is generally used to manage field crop diseases. At present, cotton cultivars with documented resistance to target spot are not available in commercial germplasm (Bowen et al. 2018; Hagan et al. 2017, 2018). Even though target spot outbreaks have been reported more frequently in specific cotton cultivars, little information exists on the differential responses of commercially available cultivars to target spot. Since documented commercial resistance is lacking, target spot management will likely rely on fungicide applications. Management of cotton leaf spot diseases with fungicides has been inconsistent with limited yield preservation (Hillocks and Chinodya 1989; Woodward et al. 2016). Consequently, even though several fungicides are registered for use in U.S. cotton production, these fungicides have been infrequently utilized due to their lack of consistent economic returns (Hagan et al. 2018). A majority of registered cotton fungicides have at least one component that belongs to the quinone outside inhibitor (QoI) fungicide class to which C. cassiicola resistance has previously been documented in other crops (Ishii et al. 2007; MacKenzie et al. 2018). Thus, determining the efficacy of available fungicides for C. cassiicola control is critical to developing regional management strategies for target spot of cotton. The current study's objective was to evaluate the effectiveness of fungicide application programs on two cotton cultivars hypothesized to differ in target spot susceptibility as a means to manage the disease and protect cotton yield in the southeastern United States.

\section{Materials and Methods}

Experimental locations. The study was conducted over a period of 3 years with field experiments established at university experiment stations in four locations across four states in 2014 (Quincy, FL; Attapulgus, GA; St. Joseph, LA; Suffolk, VA), five locations across four states in 2015 (Brewton, AL; Jay, FL; Quincy, FL; Stoneville, MS; Jackson, TN), and eight locations across five states in 2016 (Brewton, AL; Jay, FL; Attapulgus, GA; Camilla, GA; St. Joseph, LA; Winnsboro, LA; Stoneville, MS; Jackson, TN) for a total of 17 site-years. However, two locations (Jay, FL; 2015 and 2016) were removed from the comprehensive set of data due to sprayer contamination. Therefore, the total number of locations was set at 15 site-years for the analyses outlined below. Specific locations, site characteristics, planting dates, and harvest dates are indicated in Table 1. Cotton was planted within the normal planting date range at each location, except at Attapulgus, GA in 2014, where planting was delayed because of dry conditions. Row spacing varied according to local agronomic practices and ranged from $91.4 \mathrm{~cm}$ ( $n=8$ site-years) to $101.6 \mathrm{~cm}$ ( $n=4$ site-years) between each planted row with the remainder ( $n=3$ site-years) using $96.5 \mathrm{~cm}$. Fallow alleys were used between blocks. At each location, cotton was managed according to state Cooperative Extension guidelines with regard to use of herbicides, fertility, insecticides, plant growth regulators, and defoliation of the cotton crop. Daily cumulative precipitation, and mean minimum and maximum air temperatures at approximately $2 \mathrm{~m}$, were obtained from weather stations located within $5 \mathrm{~km}$ of each experimental site. Where available, 30-year data norms (i.e., 1981 to 2010; https:// www.ncdc.noaa.gov/cdo-web/datatools/normals) were obtained to make comparisons between conditions during the study period and the prevailing environment over time, except in the case of the locations in Georgia (www.georgiaweather.net), which were based on climate norms created from 68 years of data (1948 to 2016). The minimum and maximum temperature readings from each weather station location were used to calculate a temperature oscillation based on the differences between the average minimum and maximum temperatures.

Treatments and experimental design. Two cultivars hypothesized to vary in susceptibility to target spot based on reported incidence and severity of the disease in grower fields and research plots (Hagan 2014; Hagan et al. 2013, 2015, 2018) were compared in this study: PhytoGen 499 WRF (PHY499, PhytoGen Cottonseed, Dow AgroSciences, Indianapolis, IN) and Deltapine 1137 B2RF (DPL1137, Deltapine, Monsanto, St. Louis, MO). A nontreated control and four fungicides were evaluated: azoxystrobin (as 0.44 liter/ha of Quadris 2.08 SL, Syngenta Crop Protection, Greensboro, NC), flutriafol (as 0.51 liter/ha of Topguard SC, FMC Corporation, Philadelphia, PA), pyraclostrobin (as 0.44 liter/ha of Headline SC, BASF Corporation, Research Triangle Park, NC), and pyraclostrobin + fluxapyroxad (as 0.29 liter/ha of Priaxor SC, BASF Corporation).

Table 1. Year, location, planting date, date of disease onset, and fungicide application dates for field experiments evaluating fungicide programs for management of target spot in cotton in the southeastern United States

\begin{tabular}{|c|c|c|c|c|c|c|c|c|}
\hline Year & Location $^{\text {a }}$ & $\begin{array}{l}\text { Date of planting } \\
\text { (DOP) }\end{array}$ & $\begin{array}{c}\text { Date of disease } \\
\text { onset (DDO) }\end{array}$ & $\begin{array}{l}\text { DOP to } \\
\text { DDO }^{\mathbf{b}}\end{array}$ & $\begin{array}{c}\text { 1st fungicide } \\
\text { application (FA1) }\end{array}$ & $\begin{array}{l}\text { DDO to } \\
\text { FA1 }\end{array}$ & $\begin{array}{c}\text { 2nd fungicide } \\
\text { application (FA2) }\end{array}$ & $\begin{array}{l}\text { DDO to } \\
\text { FA2 }\end{array}$ \\
\hline \multirow[t]{4}{*}{2014} & Qui, FL & 4 Jun & 25 Aug & 82 & 6 Aug & -19 & $21 \mathrm{Aug}$ & -4 \\
\hline & Att, GA & 24 Jun & $1 \mathrm{Sep}$ & 69 & $28 \mathrm{Aug}$ & -4 & $11 \mathrm{Sep}$ & 10 \\
\hline & StJ, LA & 23 May & $17 \mathrm{Jul}$ & 55 & $24 \mathrm{Jul}$ & 7 & 7 Aug & 21 \\
\hline & Suf, VA & 20 May & $1 \mathrm{Sep}$ & 104 & $22 \mathrm{Jul}$ & -41 & 5 Aug & -27 \\
\hline \multirow[t]{4}{*}{2015} & Bre, AL & 5 May & $21 \mathrm{Jul}$ & 77 & $9 \mathrm{Jul}$ & -12 & $22 \mathrm{Jul}$ & 1 \\
\hline & Qui, FL & 13 May & 1 Aug & 80 & $22 \mathrm{Jul}$ & -10 & 5 Aug & 4 \\
\hline & Sto, MS & 7 May & $8 \mathrm{Jul}$ & 62 & $14 \mathrm{Jul}$ & 6 & $29 \mathrm{Jul}$ & 21 \\
\hline & Jac, TN & 6 May & $24 \mathrm{Jul}$ & 79 & 12 Aug & 19 & 27 Aug & 34 \\
\hline \multirow[t]{7}{*}{2016} & Bre, AL & $20 \mathrm{Apr}$ & $19 \mathrm{Jul}$ & 90 & $18 \mathrm{Jul}$ & -1 & 2 Aug & 14 \\
\hline & Att, GA & 12 May & 15 Aug & 95 & $27 \mathrm{Jul}$ & -19 & 18 Aug & 3 \\
\hline & Cam, GA & 17 May & 1 Aug & 76 & $20 \mathrm{Jul}$ & -12 & 5 Aug & 4 \\
\hline & StJ, LA & 11 May & $22 \mathrm{Jul}$ & 72 & $8 \mathrm{Jul}$ & -14 & $22 \mathrm{Jul}$ & 0 \\
\hline & Win, LA & 5 May & $25 \mathrm{Jul}$ & 81 & $12 \mathrm{Jul}$ & -13 & $27 \mathrm{Jul}$ & 2 \\
\hline & Sto, MS & $26 \mathrm{Apr}$ & $20 \mathrm{Jul}$ & 85 & $20 \mathrm{Jul}$ & 0 & 6 Aug & 17 \\
\hline & $\mathrm{Jac}, \mathrm{TN}$ & 5 May & 3 Aug & 90 & $27 \mathrm{Jul}$ & -7 & 10 Aug & 7 \\
\hline
\end{tabular}

\footnotetext{
${ }^{\text {a }}$ Qui = Quincy; Att = Attapulgas; StJ = St. Joseph; Suf = Suffolk; Bre = Brewton; Sto = Stoneville; Jac = Jackson; Cam = Camilla; Win = Winnsboro.
}

$\mathrm{b}$ Presents the difference in number of days between planting and initial disease observed at each location. 
In the first year of the study, fungicide treatments consisted of 1) a single application at first bloom and 2) an application at first bloom followed by a second application 14 days later. Observations in 2014 indicated that date of disease onset varied relative to flowering. Consequently, greater flexibility of fungicide application timings was included in the experimental design in the second 2 years to accommodate locations where disease typically occurs later in the growing season (postflowering). In 2015 and 2016, fungicide treatments consisted of 1) a single application at disease onset, but no later than 5 weeks after first bloom, or 2) an application at disease onset followed by a second application 14 days later. Specific application timings for each experiment are indicated in Table 1. Fungicides at each location were applied using the available spray equipment, but in general consisted of either a $\mathrm{CO}_{2}$-pressurized back-pack sprayer $(n=2)$ or high-clearance spray applicators $(n=13)$ that relied on compressed air. Applications were made in a water volume that ranged between 93 ( $n=2$ site-years) and $187(n=2$ site-years) liters/ha depending on the specific location with the majority of the applications made between this range ( $n=11$ site-years). Spray tip selection varied across locations, but all were acceptable to provide adequate coverage. Treatments were applied to field plots in a full factorial, randomized complete block design with two cultivars, two application treatments (one or two applications), and five fungicide treatments (four fungicide products plus a nontreated control).

Disease and yield assessments. Following the first observation of target spot lesions, disease severity and target spot-associated defoliation were evaluated biweekly from the center two rows of each plot following the first observations of lesions. Disease severity was visually evaluated as an estimate of the percentage of leaf area (0 to $100 \%$ ) exhibiting target spot lesions; ratings were typically conducted as a whole plot assessment. Visual assessments of defoliation as a result of target spot were also made using a 0 to $100 \%$ scale from the bottom of the plant moving up the plant into the upper canopy. A disease severity index (DSI) was calculated using the percent disease severity as well as defoliation values and relying on the formula DSI $=$ disease severity $\times$ disease defoliation/100 (Kandel et al. 2016).

The center two rows of each plot were harvested with a machine picker modified for small-plot research. The total weight per plot was used to calculate seed cotton yield. A subsample from each plot was ginned at each location with a table-top 10-saw gin (e.g., Continental Type 10, Continental Gin Company, Lubbock, TX) to separate lint and seed, and percent gin turnout was used to calculate lint yield. Gin turnout (\%) was calculated by subtracting the weight of lint without cottonseed to determine lint yield.

Statistical analyses. Analysis of variance for individual trials. Data were analyzed in RStudio (Version 1.0.136, RStudio, Inc.). Analysis of variance (ANOVA) was performed using a linear mixed effects model in the lme 4 and lmerTest packages (versions 1.1-12 and 2.0-33, respectively) for the variables of defoliation, severity, cottonseed yield, and lint yield. A separate ANOVA was performed for each experiment because cultivar yield responses differed across the sites and years. Cultivar, fungicide product, and application number were treated as fixed factors and replication was used as a random factor.

Quantitative synthesis of fungicide efficacy based on metaanalysis. Because ANOVA for the individual site locations indicated an effect of year and location for the fungicide treatments, a metaanalysis was performed to evaluate the treatment effects (fungicide, timing, and cultivar) across year and location. A multivariate random effects model meta-analysis was performed to evaluate the overall efficacy of fungicide treatments relative to the nontreated (Kandel et al. 2018; Madden and Paul 2011; Whitehead 2002). Random-effects meta-analyses were performed using the metafor package in $\mathrm{R}$ with the method statement set to REML (restricted maximum likelihood). The log response ratio was calculated by:

\section{$\ln ($ fungicide treatment $)-\ln ($ non-treated control $)$}

The mean square error (MSE) was used to calculate the sampling variance, computed as $v_{i}=(2 * V) / r$, where the $i$ subscript refers to the $i$ th study, $r$ the number of replicates within each study, and $V$ is the mean square error from the analysis of variance for the respective response. The variance $\left(v_{i}\right)$ of the meta-analysis was used to assess the impact of each trial $(\mathrm{K})$ on the results. Mean percent defoliation, seed cotton yield, and lint yield from fungicide treated and nontreated plots were used to evaluate the efficacy of the fungicide products relative to the nontreated. Two- and three-way treatment interaction effects were not consistent among response variables, and overall effect sizes were not biologically significant for application timing, so this variable was removed from the final meta-analysis. Preliminary meta-analysis also confirmed that the addition of this variable did not improve the model fit statistics or change the overall conclusions. Overall, the mean percent control and yield savings and their respective confidence intervals $(\mathrm{CI})$ were back transformed from the $\log$ response ratio $(\bar{L})$ using the formula $\bar{R}=[\exp (\bar{L})-1] \times 100$.

\section{Results}

Target spot onset and severity varied among locations and years (Tables 1 and 2). Disease was observed within 1 week of first bloom in GA (2014), LA (2014), FL (2015, 2016), and MS (2015); for the other site-years, disease onset varied from 2 to 6 weeks following first bloom. Due to variation in date of disease onset, not all locations and years had multiple disease evaluation dates. Thus, to make comparisons across experiments, data for the final rating date at each siteyear are presented. Severity and defoliation ratings indicated that PHY499 generally had more disease than DPL1137. Therefore, the mean rating of the nontreated plots of PHY 499 were used as a benchmark for disease expression. Disease severity of the nontreated PHY499 on the final evaluation date ranged from $1.2 \%$ of the leaf area (VA, 2014) to 77.5\% (LA, 2014); final defoliation ranged from $30.2 \%$ (GA, 2016) to 76.8\% (AL, 2015). A consistent relationship between defoliation and disease severity measured as an estimate of percent leaf area with lesions was not observed, and some siteyears with high ( $>40 \%$ ) levels of defoliation on the final evaluation date had less than $5 \%$ target spot severity (Table 2). Defoliation ratings progressively increased at the majority of sites, because the rate of leaf loss to disease was greater than additional growth of the upper plant canopy. However, severity data were erratic. At each observation, the apparent percentage of leaf area compromised by lesions was dependent on the rate of infection and that of premature defoliation. Heavily diseased leaves defoliated quickly, and in some cases observations of high disease severity were followed by low severity in the remaining canopy because the previously symptomatic leaves had prematurely defoliated.

Mean temperature was greater in $2015\left(27.1^{\circ} \mathrm{C}\right)$ and $2016\left(28.1^{\circ} \mathrm{C}\right)$ compared with $2014\left(25.9^{\circ} \mathrm{C}\right)$ (Table 2$)$. Over the study period, the bulk of the site-years $(n=9)$ had rainfall totals below normal for that location, and six site-years had greater rainfall than normal (Table 2). No relationship between temperature and disease severity index (DSI) was observed $(P=0.87)$. However, there was a trend toward increasing DSI with decreasing temperature oscillations $\left(r^{2}=0.31\right.$, $P=0.06)$ and increasing total rainfall $\left(r^{2}=0.26, P=0.07\right)$ (Table 2). Such an observation is consistent with greater disease incidence in wetter versus drier years where diurnal variation in temperature would be dampened by high humidity consistent with conditions favorable for fungal growth and sporulation.

When analyzed across all site-years, main treatment effects (cultivar, number of applications, and fungicide) significantly affected disease severity $(P<0.001)$, defoliation $(P<0.001)$, and yield $(P<$ $0.001)$, but there were treatment by location interactions, so each site-year (experiment) was analyzed separately. Target spot severity differed between the two cotton cultivars in $73 \%$ of the site-years (Table 3). In all cases, disease severity was greater on PHY499 (mean $=20.0 \%$ ) compared with DPL1137 (mean $=16.0 \%$ ). Severity differed between one and two fungicide applications $40 \%$ of the time, but the magnitude of the difference was small; two applications reduced target spot severity by $0.1-10.5 \%$ more than one application (mean difference $=1.6 \%, P<0.01$ ). Fungicide treatment reduced target spot severity in one-third of the experiments with maximum differences between the nontreated and fungicide treatments ranging 
from 0.0 to $21.2 \%$ (mean disease severity $=2.9 \%$ ). In four of the five site-years where fungicide treatments reduced target spot severity, pyraclostrobin + fluxapyroxad provided the greatest reduction in observable target spot symptoms (Table 3 ). In a majority of the experiments, only the main treatment effects were significant, but in the two 2016 GA locations, there were fungicide by application number and fungicide by application by cultivar interactions (Supplementary Table S1).

Table 2. Defoliation, disease severity, and disease severity index values for the cultivar Phytogen 499 WRF nontreated checks and environmental variables for years and locations of the fungicide trials conducted in the southeastern United States

\begin{tabular}{|c|c|c|c|c|c|c|c|c|c|c|}
\hline \multirow[b]{2}{*}{ Year } & \multirow[b]{2}{*}{ Location $^{\mathbf{a}}$} & \multicolumn{2}{|c|}{ Percent } & \multirow[b]{2}{*}{ DSI $^{\mathbf{b}}$} & \multirow[b]{2}{*}{ Avg. temp $\left({ }^{\circ} \mathrm{C}\right)^{\mathrm{c}}$} & \multirow{2}{*}{$\begin{array}{l}\text { Day max } \\
\text { temp 32d }\end{array}$} & \multirow[b]{2}{*}{ Oscillation $^{\mathbf{e}}$} & \multirow{2}{*}{$\begin{array}{c}\text { Total rain } \\
(\mathbf{c m})^{\mathbf{f}}\end{array}$} & \multirow{2}{*}{$\begin{array}{l}\text { \# days with } \\
\text { raing }\end{array}$} & \multirow{2}{*}{$\begin{array}{c}\text { Deviation from } \\
\text { norm }^{\mathrm{h}}\end{array}$} \\
\hline & & Defoliation & Severity & & & & & & & \\
\hline \multirow[t]{4}{*}{2014} & Qui, FL & 37.5 & 41.2 & 15.9 & 26.4 & 37 & 10.9 & 21.1 & 21 & -14.7 \\
\hline & Att, GA & 45.0 & 4.0 & 1.3 & 27.1 & 45 & 12.2 & 13.0 & 20 & -26.4 \\
\hline & StJ, LA & 53.5 & 77.5 & 41.3 & 25.2 & 20 & 7.0 & 33.7 & 19 & +12.4 \\
\hline & Suf, VA & 40.0 & 1.2 & 0.4 & 24.7 & 19 & 11.3 & 27.7 & 20 & -7.6 \\
\hline \multirow[t]{4}{*}{2015} & Bre, AL & 76.7 & 3.9 & 2.9 & 27.8 & 50 & 11.8 & 25.2 & 22 & -8.2 \\
\hline & Qui, FL & 67.5 & 50.0 & 33.8 & 26.8 & 46 & 10.6 & 27.4 & 35 & -8.5 \\
\hline & Sto, MS & 38.1 & 13.7 & 5.1 & 28.0 & 49 & 11.5 & 9.9 & 12 & -5.1 \\
\hline & $\mathrm{Jac}, \mathrm{TN}$ & 48.9 & 21.7 & 10.7 & 25.6 & 30 & 12.0 & 22.9 & 17 & +2.9 \\
\hline \multirow[t]{7}{*}{2016} & Bre, AL & 68.2 & 3.9 & 2.7 & 27.6 & 48 & 10.9 & 25.1 & 34 & -8.3 \\
\hline & Att, GA & 30.2 & 4.4 & 1.9 & 27.8 & 47 & 11.1 & 27.5 & 30 & -11.9 \\
\hline & Cam, GA & 47.5 & 5.5 & 2.9 & 28.3 & 58 & 11.6 & 30.1 & 31 & +1.6 \\
\hline & StJ, LA & 66.9 & 18.7 & 12.8 & 28.6 & 56 & 11.6 & 21.7 & 25 & -0.4 \\
\hline & Win, LA & 70.6 & 22.5 & 16.2 & 27.9 & 61 & 14.8 & 27.7 & 18 & +9.1 \\
\hline & Sto, MS & 37.5 & 51.2 & 21.6 & 28.4 & 52 & 10.3 & 30.5 & 31 & +15.5 \\
\hline & $\mathrm{Jac}, \mathrm{TN}$ & 54.4 & 16.2 & 8.9 & 27.5 & 43 & 10.7 & 27.5 & 27 & +7.5 \\
\hline
\end{tabular}

a Qui = Quincy; Att = Attapulgas; StJ = St. Joseph; Suf = Suffolk; Bre = Brewton; Sto = Stoneville; Jac = Jackson; Cam = Camilla; Win = Winnsboro.

b DSI = disease severity index calculated using percent severity and defoliation values with the formula: DSI $=$ disease severity $\times$ disease defoliation/100.

c Average temperature recorded for the months of July and August.

d Number of days in July and August that have max temperatures greater than $32^{\circ} \mathrm{C}$ out of a total of 62 days.

e Average daily temperature oscillation which was determined as the difference between the max and min temperature readings for the weather station.

f Total amount of rainfall $(\mathrm{cm})$ from July 1 st to August 31 st.

$\mathrm{g}$ Total number of days with rainfall of $0.0254 \mathrm{~cm}$ or greater from July 1st to August $31 \mathrm{st}$ (62 days total).

h Deviation from the norm represents the difference in rainfall $(\mathrm{cm})$ for the combined July + August 30-year normal as defined by the normal data for each representative weather station (except in the case of the GA locations which are based on 68 years of data; www.georgiaweather.net). Values with a negative were below the norm, while values with a positive were above the norm.

Table 3. Least square means of the main effects of cultivar, fungicide, and number of fungicide applications on target spot severity of cotton across 15 site-years

\begin{tabular}{|c|c|c|c|c|c|c|c|c|c|c|c|c|c|c|c|}
\hline \multirow[b]{3}{*}{ Variables } & \multicolumn{15}{|c|}{ Least square means of target spot severity $(\%)^{a}$} \\
\hline & \multicolumn{4}{|c|}{2014} & \multicolumn{4}{|c|}{2015} & \multicolumn{7}{|c|}{2016} \\
\hline & $\begin{array}{l}\text { Qui, } \\
\text { FL }\end{array}$ & $\begin{array}{l}\text { Att, } \\
\text { GA }\end{array}$ & $\begin{array}{l}\text { St.J, } \\
\text { LA }\end{array}$ & $\begin{array}{l}\text { Suf, } \\
\text { VA }\end{array}$ & $\begin{array}{c}\text { Bre, } \\
\text { AL }\end{array}$ & $\begin{array}{l}\text { Qui, } \\
\text { FL }\end{array}$ & $\begin{array}{l}\text { Sto, } \\
\text { MS }\end{array}$ & $\begin{array}{l}\text { Jac, } \\
\text { TN }\end{array}$ & $\begin{array}{c}\text { Bre, } \\
\text { AL }\end{array}$ & $\begin{array}{c}\mathbf{A t t}, \\
\mathbf{G A}\end{array}$ & $\begin{array}{c}\text { Cam, } \\
\text { GA }\end{array}$ & $\begin{array}{l}\text { St.J, } \\
\text { LA }\end{array}$ & $\begin{array}{c}\text { Win, } \\
\text { LA }\end{array}$ & $\begin{array}{l}\text { Sto, } \\
\text { MS }\end{array}$ & $\begin{array}{l}\text { Jac, } \\
\text { TN }\end{array}$ \\
\hline \multicolumn{16}{|l|}{ Cultivar } \\
\hline DPL1137 & 42.3 & 2.0 & 39.0 & 1.3 & 3.4 & 41.0 & 15.5 & 15.6 & 1.5 & 3.1 & 2.2 & 14.3 & 18.0 & 27.9 & 13.7 \\
\hline PHY499 & 45.3 & 2.4 & 76.8 & 1.7 & 4.1 & 48.9 & 15.3 & 20.0 & 3.5 & 3.1 & 3.5 & 19.3 & 25.8 & 45.2 & 15.4 \\
\hline Diff & 3.0 & 0.4 & 37.8 & 0.5 & 0.7 & 7.9 & 0.2 & 4.3 & 2.0 & 0.0 & 1.3 & 5.0 & 7.9 & 17.4 & 1.7 \\
\hline$P>F$ & 0.13 & $<0.01$ & $<0.01$ & 0.10 & $<0.01$ & $<0.01$ & 0.87 & $<0.01$ & $<0.01$ & 0.98 & $<0.01$ & $<0.01$ & $<0.01$ & $<0.01$ & 0.01 \\
\hline \multicolumn{16}{|l|}{ Fungicide $^{c}$} \\
\hline Nontreated & 41.3 & 2.5 & 57.8 & 1.5 & 3.8 & 45.0 & 15.9 & 19.3 & 2.8 & 4.8 & 4.1 & 17.2 & 20.0 & 40.6 & 16.6 \\
\hline AZOX & 41.3 & 2.1 & 57.8 & 1.3 & 3.8 & 44.7 & 16.3 & 18.1 & 2.5 & 3.7 & 2.0 & 15.9 & 20.9 & 27.4 & 15.5 \\
\hline PYRA & 45.0 & 2.0 & 57.8 & 1.9 & 4.1 & 44.7 & 13.6 & 19.4 & 2.4 & 2.9 & 3.7 & 16.6 & 18.8 & 24.2 & 13.8 \\
\hline PYRA + FLUX & 48.8 & 1.8 & 58.4 & 1.5 & 3.6 & 45.3 & 16.9 & 17.8 & 2.0 & 2.2 & 2.1 & 18.4 & 22.8 & 19.4 & 12.2 \\
\hline FLUT & 42.5 & 2.3 & 57.5 & 1.4 & 3.5 & 45.0 & 14.4 & 14.4 & 2.7 & 1.9 & 2.2 & 15.6 & 19.1 & 39.4 & 14.7 \\
\hline Max diff & 0.0 & 0.7 & 0.3 & 0.2 & 0.3 & 0.3 & 2.4 & 4.9 & 0.8 & 2.9 & 2.1 & 1.6 & 1.3 & 21.2 & 4.4 \\
\hline$P>F$ & 0.09 & $<0.01$ & 1.00 & 0.71 & 0.44 & 0.99 & 0.43 & 0.15 & 0.03 & 0.15 & $<0.01$ & 0.06 & 0.16 & 0.01 & $<0.01$ \\
\hline \multicolumn{16}{|l|}{ Application $(s)^{\mathrm{d}}$} \\
\hline One & 43.3 & 2.2 & 58.4 & 1.6 & 4.0 & 45.5 & 15.2 & 19.5 & 2.8 & 3.3 & 3.2 & 17.0 & 21.1 & 41.8 & 16.6 \\
\hline Two & 44.3 & 2.1 & 57.4 & 1.4 & 3.5 & 44.4 & 15.6 & 16.1 & 2.2 & 2.9 & 2.5 & 16.5 & 19.5 & 31.3 & 14.5 \\
\hline Diff & 1.0 & 0.1 & 1.0 & 0.3 & 0.5 & 1.1 & 0.4 & 3.3 & 0.6 & 0.4 & 0.7 & 0.5 & 1.6 & 10.5 & 2.1 \\
\hline$P>F$ & 0.61 & 0.34 & 0.58 & 0.35 & 0.02 & 0.26 & 0.72 & 0.02 & $<0.01$ & 0.56 & 0.02 & 0.45 & 0.15 & 0.02 & $<0.01$ \\
\hline
\end{tabular}

${ }^{\mathrm{a}}$ Qui = Quincy; Att = Attapulgas; StJ = St. Joseph; Suf = Suffolk; Bre = Brewton; Sto = Stoneville; Jac = Jackson; Cam = Camilla; Win = Winnsboro. Values represent mean seed cotton yield for the specified treatments. Differences (Diff) is the absolute difference between the least square mean values. Values and the maximum difference (Max Diff) of the best fungicide yield compared with the control is presented.

b Cultivar treatment with PHY499 = PhytoGen 499 WRF (more susceptible to target spot) and DPL1137= Deltapine 1137 B2RF (more tolerant to target spot).

c Fungicide product active ingredients applied once or twice at each trial location; however, combined for presentation. $\mathrm{NTC}=$ nontreated control; $\mathrm{AZOX}=$ azoxystrobin (as Quadris); FLUT = flutriafol (as Topguard); PYRA = pyraclostrobin (as Headline); and PYRA + FLUX = pyraclostrobin + fluxapyroxad (as Priaxor). Max diff $=$ the maximum percent severity reduction compared with the NTC.

${ }^{\mathrm{d}}$ Fungicide application timing differed to where in 2014 the applications were made at first white flower (one application) with a second application made 14 days postapplication (two applications). Application timing in 2015 and 2016 occurred at first observation of target spot, followed by 14 days postapplication. Diff $=$ the absolute difference between the least square mean values. 
Similar to disease severity, premature defoliation due to target spot was greater on PHY499 $($ mean $=44.0 \%)$ compared with DPL1137 $($ mean $=27.9 \%)$ at 12 of the 15 site-years (Table 4$)$. In general, the difference in defoliation between the two cultivars increased as the overall percent defoliation increased. Significant interactions were observed among cultivar and the other treatment factors in eight of the experiments, but interaction effects were inconsistent across site-years. The number of fungicide applications significantly impacted defoliation in almost half of the experiments $(n=7)$, but the magnitude of the difference was small $(4.7-11.7 \%$ in site-years with significant differences, mean across all site-years $=4.7 \%$ ). Fungicide treatments reduced defoliation in nine of the 15 experiments, but fungicide products varied in their effectiveness (Table 4). Differences in defoliation between the nontreated and the best fungicide treatment ranged from 1.3 to $32.0 \%$ (mean $=13.9 \%)$. Pyraclostrobin + fluxapyroxad treatments had the lowest defoliation in a majority of the site-years where fungicides significantly reduced defoliation.

Cotton yield was impacted by all treatment factors, but responses varied among site-years (Table 5). Seed cotton yield differed between the two cultivars in 10 of the 15 site-years, with PHY499 and DPL1137 producing the greatest yield at six and four of the site-years, respectively. However, there were interactions among cultivar and other treatment factors in $\operatorname{AL}(2015,2016)$, the FL location in 2015, and both GA locations in 2016. In 2016, two fungicide applications resulted in significantly greater yield in half of the experiments, but for the other site-years, application number did not impact yield. Seed cotton yield did not vary among fungicide treatments at any location in 2014 or 2015, but in 2016, fungicide treatments preserved yield at four of the seven locations; fungicides significantly reduced premature defoliation due to target spot at these same locations in 2016 (Table 4) with fungicide treatment increasing seed cotton yield by $0.2-20.8 \%$ compared with the nontreated (Table 5). The best fungicide treatment, pyraclostrobin + fluxapyroxad, preserved yield $87.5 \%$ of the time compared with the nontreated. Treatment responses for lint yield were similar to those for seed cotton yield. Differences between lint yield of the nontreated and each fungicide are compared across all site-years in Figure 1. The magnitude of the lint yield response varied among fungicides, but ranged from $-140 \mathrm{~kg} / \mathrm{ha}$ to $372 \mathrm{~kg} / \mathrm{ha}$ with an overall average of $59 \mathrm{~kg} / \mathrm{ha}$. Two fungicide applications resulted in lint yield up to $157 \mathrm{~kg} / \mathrm{ha}$ greater than one application (mean across all trials = $30 \mathrm{~kg} / \mathrm{ha}$ ) (data not presented).

Since the analysis of variance for individual site-years indicated effects of year and location for treatments, a meta-analysis was performed to evaluate the effects of fungicide and cotton cultivar across site-years (Tables 6 and 7). All four fungicides reduced defoliation on PHY499, while azoxystrobin and pyraclostrobin + fluxapyroxad reduced defoliation on DPL1137 (Table 6). Even though all fungicides reduced target spot associated defoliation, only pyraclostrobin and pyraclostrobin + fluxapyroxad had an effect on seed cotton yield, and the magnitude of the yield loss protection was greater on PHY499 than for DLP1137 (Table 7). Results for lint yield were similar, but there was an additional small effect with the flutriafol treatment on DPL1137 (Table 7).

\section{Discussion}

Outbreaks of target spot on cotton have become increasingly common in the southeastern United States, but impacts of the disease on yield and strategies to manage the disease are not well understood or documented. The current study is the first of its kind to examine the effects of cultivar and fungicide programs on target spot development and cotton yield across multiple production areas from which the disease has been reported. A multiyear, regional study allowed for the evaluation of treatments across diverse cropping and environmental conditions. Since occurrences of target spot outbreaks are highly variable, a majority of this study's site-years had low levels and/or late onset of disease; however, when disease onset was at or prior to flowering and severe, over $300 \mathrm{~kg} / \mathrm{ha}$ of lint yield were lost, which indicates target spot has high economic damage potential. Disease severity and yield

Table 4. Least square means of the main effects of cultivar, fungicide, and number of applications on defoliation of cotton due to target spot across 15 site-years

\begin{tabular}{|c|c|c|c|c|c|c|c|c|c|c|c|c|c|c|c|}
\hline \multirow[b]{3}{*}{ Variables } & \multicolumn{15}{|c|}{ Least square means of defoliation $(\%)^{\mathbf{a}}$} \\
\hline & \multicolumn{4}{|c|}{2014} & \multicolumn{4}{|c|}{2015} & \multicolumn{7}{|c|}{2016} \\
\hline & $\begin{array}{l}\text { Qui, } \\
\text { FL }\end{array}$ & $\begin{array}{l}\text { Att, } \\
\text { GA }\end{array}$ & $\begin{array}{l}\text { StJ, } \\
\text { LA }\end{array}$ & $\begin{array}{l}\text { Suf, } \\
\text { VA }\end{array}$ & $\begin{array}{l}\text { Bre, } \\
\text { AL }\end{array}$ & $\begin{array}{l}\text { Qui, } \\
\text { FL }\end{array}$ & $\begin{array}{l}\text { Sto, } \\
\text { MS }\end{array}$ & $\begin{array}{l}\text { Jac, } \\
\text { TN }\end{array}$ & $\begin{array}{l}\text { Bre, } \\
\text { AL }\end{array}$ & $\begin{array}{l}\text { Att, } \\
\text { GA }\end{array}$ & $\begin{array}{c}\text { Cam, } \\
\text { GA }\end{array}$ & $\begin{array}{l}\text { StJ, } \\
\text { LA }\end{array}$ & $\begin{array}{l}\text { Win, } \\
\text { LA }\end{array}$ & $\begin{array}{l}\text { Sto, } \\
\text { MS }\end{array}$ & $\begin{array}{l}\text { Jac, } \\
\text { TN }\end{array}$ \\
\hline \multicolumn{16}{|l|}{ Cultivar $^{\mathrm{b}}$} \\
\hline DPL1137 & 37.3 & 5.9 & 24.3 & 38.0 & 31.0 & 46.1 & 35.4 & 35.3 & 22.9 & 21.4 & 20.5 & 31.8 & 31.8 & 16.1 & 21.3 \\
\hline PHY499 & 40.8 & 25.1 & 50.0 & 38.4 & 68.5 & 64.9 & 34.0 & 45.3 & 51.4 & 17.9 & 32.8 & 59.6 & 60.9 & 30.9 & 39.6 \\
\hline Diff & 3.5 & 19.2 & 25.8 & 0.4 & 37.5 & 18.8 & 1.4 & 10.0 & 28.5 & 3.5 & 12.3 & 27.8 & 29.1 & 14.8 & 18.3 \\
\hline$P>F$ & 0.05 & $<0.01$ & $<0.01$ & 0.89 & $<0.01$ & $<0.01$ & 0.58 & $<0.01$ & $<0.01$ & 0.33 & $<0.01$ & $<0.01$ & $<0.01$ & $<0.01$ & $<0.01$ \\
\hline \multicolumn{16}{|l|}{ Fungicide $^{\mathrm{c}}$} \\
\hline NTC & 36.9 & 27.3 & 36.6 & 37.2 & 61.0 & 56.3 & 39.4 & 43.9 & 48.3 & 31.3 & 40.6 & 53.4 & 51.6 & 30.6 & 42.2 \\
\hline AZOX & 35.0 & 15.6 & 34.4 & 39.1 & 53.8 & 56.3 & 31.3 & 41.3 & 40.0 & 20.0 & 11.7 & 45.6 & 50.6 & 23.4 & 33.3 \\
\hline PYRA & 40.0 & 11.3 & 36.3 & 37.8 & 47.7 & 54.7 & 37.2 & 44.7 & 34.6 & 15.9 & 40.9 & 49.4 & 40.0 & 20.9 & 25.5 \\
\hline PYRA+FLUX & 44.4 & 7.8 & 35.0 & 40.9 & 39.0 & 52.8 & 35.3 & 39.1 & 24.8 & 13.8 & 8.6 & 37.2 & 43.1 & 18.1 & 17.2 \\
\hline FLUT & 38.8 & 15.3 & 35.9 & 35.9 & 47.3 & 57.5 & 30.3 & 32.5 & 38.0 & 17.0 & 31.3 & 42.8 & 46.3 & 24.4 & 34.1 \\
\hline Max diff & 1.9 & 19.5 & 2.2 & 1.3 & 22.0 & 3.5 & 9.1 & 11.4 & 23.5 & 17.4 & 32.0 & 16.2 & 11.6 & 12.5 & 25.0 \\
\hline$P>F$ & 0.02 & $<0.01$ & 0.95 & 0.79 & $<0.01$ & 0.54 & 0.12 & 0.01 & $<0.01$ & 0.03 & $<0.01$ & $<0.01$ & 0.22 & 0.08 & $<0.01$ \\
\hline \multicolumn{16}{|l|}{$\operatorname{Application}(s)^{\mathrm{d}}$} \\
\hline One & 38.8 & 17.3 & 35.8 & 37.3 & 52.1 & 57.9 & 30.4 & 43.4 & 40.5 & 18.0 & 25.0 & 47.8 & 49.9 & 25.4 & 36.3 \\
\hline Two & 39.3 & 13.6 & 35.5 & 39.3 & 47.4 & 53.1 & 39.0 & 37.1 & 33.8 & 21.2 & 28.2 & 43.6 & 42.8 & 21.6 & 24.6 \\
\hline Diff & 0.5 & 3.7 & 0.3 & 2.0 & 4.7 & 4.8 & 8.6 & 6.3 & 6.7 & 3.2 & 3.2 & 4.2 & 7.1 & 3.8 & 11.7 \\
\hline$P>F$ & 0.78 & 0.17 & 0.89 & 0.42 & 0.01 & 0.01 & $<0.01$ & 0.01 & $<0.01$ & 0.37 & 0.41 & 0.10 & 0.05 & 0.18 & $<0.01$ \\
\hline
\end{tabular}

${ }^{\mathrm{a}}$ Qui = Quincy; Att = Attapulgas; StJ = St. Joseph; Suf = Suffolk; Bre = Brewton; Sto = Stoneville; Jac $=$ Jackson; Cam = Camilla; Win $=$ Winnsboro. Values represent mean seed cotton yield for the specified treatments. Differences (Diff) is the absolute difference between the least square mean values. Values and the maximum difference (Max Diff) of the best fungicide yield compared with the control is presented.

${ }^{\mathrm{b}}$ Cultivar treatment with PHY499 = PhytoGen $499 \mathrm{WRF}$ (more susceptible to target spot) and DPL1137 = Deltapine 1137 B2RF (more tolerant to target spot).

${ }^{c}$ Fungicide product active ingredients applied once or twice at each trial location; however, combined for presentation. NTC $=$ nontreated control; AZOX $=$ azoxystrobin (as Quadris); FLUT = flutriafol (as Topguard); PYRA = pyraclostrobin (as Headline); and PYRA + FLUX = pyraclostrobin + fluxapyroxad (as Priaxor). Max diff $=$ the maximum percent severity reduction compared with the NTC.

${ }^{\mathrm{d}}$ Fungicide application timing differed to where in 2014 the applications were made at first white flower (one application) with a second application made 14 days postapplication (two applications). Application timing in 2015 and 2016 occurred at first observation of target spot, followed by 14 days postapplication. Diff = the absolute difference between the least square mean values. 
loss were greater on PHY499 compared with DPL1137, but the meta-analysis conducted as part of this study demonstrated that fungicide applications with certain products can reduce disease and protect yield of cultivars varying in target spot susceptibility and across environments.

Both target spot severity and defoliation were evaluated in the current study, but disease severity estimated as percent leaf area exhibiting lesions was poorly correlated with premature defoliation. Target spot begins in the lower canopy, moving upward during periods with a conducive, humid environment; following lesion formation, symptomatic leaves prematurely defoliate (Bowen et al. 2018; Hagan et al. 2018; Price et al. 2015). In the current study, we demonstrated that the extent to which lesions develop prior to defoliation is highly variable and likely dependent on the microclimate within the cotton canopy (Marois et al. 2004); however, measuring environmental variables within the cotton canopy during the current study was beyond the scope of the research. When describing target spot, rate and severity of lesion development may not be as useful for understanding disease impact as determining the date of disease onset, the crop's developmental stage when defoliation begins, and the subsequent rate of defoliation. Yield losses are most likely driven by loss of photosynthetically active areas of the canopy. Bowen et al. (2018) estimated that for every $10 \%$ of the lower canopy that was observed to have defoliated in late August, there was a $4 \%$ loss in yield. In the current study, yield losses as a result of target spot-induced defoliation could not be rigorously assessed since high levels of disease control following fungicide application were not consistently achieved. However, the results of our current study do support previous observations that yield losses occur with greater levels of target spot and subsequent premature defoliation (Bowen et al. 2018; Hagan 2014; Hagan et al. 2018). For all site-years with a response to fungicide treatment, defoliation of the nontreated control exceeded $40 \%$, and the fungicide treatment with the greatest level of control reduced defoliation by more than $15 \%$. The temporal and spatial components of target spot disease progress need to be studied in greater detail to determine how the timing of defoliation relative to crop developmental stage and relative position of defoliation within the canopy impacts yield.

Even though individual site-year responses were variable, overall the fungicide treatments were observed to provide positive yield savings in the current study. For example, the pyraclostrobin treatment produced an average PHY499 lint yield savings of approximately $6 \%$ with a confidence interval roughly ranging from 1 to $10 \%$. Therefore, on average, yield savings of $\$ 74.35 /$ ha and $\$ 100.28 /$ ha would be expected for crops sold at $\$ 1.54 / \mathrm{kg}$ and yield potential of 3.6 and 4.9 bales per hectare, respectively. However, on average, these returns could be greater than or less than these amounts as indicated by the confidence interval. Cultivar is also important when considering returns from fungicide inputs. The maximum yield savings per hectare was $\$ 84.72$ with the DPL1137 for a crop expected to produce 4.9 bales per hectare at the same market price. The current results indicate that while fungicides can protect yield, it is important to understand the risk of yield losses associated with the crop and disease, as well as the crop's expected yield and selling price before making a fungicide application.

The return on investment from a fungicide application is highly dependent on the expected yield saving values discussed above and the cost of the fungicide product and application. Fungicide price varies by location and the specific retailer where the fungicide is purchase, and the price received for the cotton crop varies by year, so a detailed economic analysis of the value of different fungicide programs was beyond the scope of this study. However, total fungicide costs were recently documented to exceed \$74/ha in cotton (Hagan et al. 2018). A relatively high application cost indicates that, while in some situations fungicide applications will provide a positive economic return, there will be many situations when there is no monetary benefit. Thus, it is not only important to understand the risk of yield losses associated with target spot, but also to better understand the critical factors related to disease outbreaks that lead to these losses.

A lack of disease control for some site-years in the current study suggests timing of fungicide applications was less than optimal. Initially, fungicide applications were timed to occur at first bloom;

Table 5. Least square means of the main effects of cultivar, fungicide, and number of fungicide applications on seed cotton yield across 15 site-years

\begin{tabular}{|c|c|c|c|c|c|c|c|c|c|c|c|c|c|c|c|}
\hline \multirow[b]{3}{*}{ Variables } & \multicolumn{15}{|c|}{ Least square means of seed cotton yield $(\mathrm{kg} / \mathrm{ha})^{\mathrm{a}}$} \\
\hline & \multicolumn{4}{|c|}{2014} & \multicolumn{4}{|c|}{2015} & \multicolumn{7}{|c|}{2016} \\
\hline & $\begin{array}{l}\text { Qui, } \\
\text { FL }\end{array}$ & $\begin{array}{l}\text { Att, } \\
\text { GA }\end{array}$ & $\begin{array}{l}\text { StJ, } \\
\text { LA }\end{array}$ & $\begin{array}{l}\text { Suf, } \\
\text { VA }\end{array}$ & $\begin{array}{c}\text { Bre, } \\
\text { AL }\end{array}$ & $\begin{array}{l}\text { Qui, } \\
\text { FL }\end{array}$ & $\begin{array}{l}\text { Sto, } \\
\text { MS }\end{array}$ & $\begin{array}{l}\text { Jac, } \\
\text { TN }\end{array}$ & $\begin{array}{c}\text { Bre, } \\
\text { AL }\end{array}$ & $\begin{array}{l}\text { Att, } \\
\text { GA }\end{array}$ & $\begin{array}{c}\text { Cam, } \\
\text { GA }\end{array}$ & $\begin{array}{l}\text { StJ, } \\
\text { LA }\end{array}$ & $\begin{array}{l}\text { Win, } \\
\text { LA }\end{array}$ & $\begin{array}{l}\text { Sto, } \\
\text { MS }\end{array}$ & $\begin{array}{l}\text { Jac, } \\
\text { TN }\end{array}$ \\
\hline \multicolumn{16}{|l|}{$\overline{\text { Cultivar }}$} \\
\hline DPL1137 & 4,359 & 2,283 & 1,992 & 3,863 & 4,690 & 4,648 & 3,738 & 2,792 & 3,019 & 2,877 & 1,645 & 3,117 & 3,113 & 3,839 & 5,793 \\
\hline PHY499 & 4,253 & 2,084 & 3,236 & 4,421 & 4,395 & 3,900 & 4,494 & 4,154 & 2,912 & 2,601 & 1,774 & 3,103 & 3,058 & 4,451 & 5,326 \\
\hline Diff & 106 & 199 & 1,244 & 558 & 295 & 748 & 756 & 1,362 & 107 & 276 & 129 & 14 & 56 & 612 & 467 \\
\hline$P>F$ & 0.3 & 0.13 & $<0.01$ & $<0.01$ & $<0.01$ & $<0.01$ & $<0.01$ & $<0.01$ & 0.08 & $<0.01$ & $<0.01$ & 0.81 & 0.62 & $<0.01$ & $<0.01$ \\
\hline \multicolumn{16}{|l|}{ Fungicide $^{c}$} \\
\hline NTC & 4,177 & 1,948 & 2,582 & 3,962 & 4,596 & 4,151 & 4,190 & 3,359 & 2,735 & 2,760 & 1,622 & 2,926 & 2,892 & 4,146 & 5,266 \\
\hline AZOX & 4,304 & 2,169 & 2,725 & 4,044 & 4,573 & 4,429 & 4,119 & 3,468 & 3,046 & 2,818 & 1,699 & 3,030 & 3,032 & 3,998 & 5,336 \\
\hline PYRA & 4,498 & 2,461 & 2,637 & 4,233 & 4,511 & 4,252 & 3,990 & 3,609 & 3,097 & 2,743 & 1,716 & 3,141 & 3,267 & 4,259 & 5,868 \\
\hline PYRA+FLUX & 4,277 & 2,302 & 2,347 & 4,228 & 4,528 & 4,379 & 4,191 & 3,397 & 3,177 & 2,812 & 1,783 & 3,322 & 3,169 & 4,211 & 5,574 \\
\hline FLUT & 4,275 & 2,039 & 2,779 & 4,244 & 4,504 & 4,160 & 4,091 & 3,531 & 2,771 & 2,563 & 1,727 & 3,132 & 3,068 & 4,139 & 5,753 \\
\hline Max Diff & 321 & 513 & 197 & 282 & 23 & 278 & 1 & 250 & 442 & 58 & 161 & 396 & 375 & 113 & 602 \\
\hline$P>F$ & 0.37 & 0.11 & 0.07 & 0.21 & 0.89 & 0.14 & 0.74 & 0.86 & $<0.01$ & 0.52 & 0.05 & $<0.01$ & 0.27 & 0.24 & 0.02 \\
\hline \multicolumn{16}{|l|}{ Application(s) ${ }^{\mathrm{d}}$} \\
\hline One & 4,373 & 2,177 & 2,644 & 4,142 & 4,514 & 4,264 & 4,201 & 3,484 & 2,895 & 2,712 & 1,733 & 3,061 & 3,064 & 4,182 & 5,377 \\
\hline Two & 4,239 & 2,191 & 2,584 & 4,143 & 4,570 & 4,284 & 4,031 & 3,462 & 3,036 & 2,766 & 1,686 & 3,171 & 3,107 & 4,120 & 5,742 \\
\hline Diff & 134 & 14 & 60 & 2 & 56 & 20 & 170 & 22 & 141 & 55 & 46 & 110 & 43 & 62 & 365 \\
\hline$P>F$ & 0.19 & 0.91 & 0.54 & 0.98 & 0.43 & 0.81 & 0.11 & 0.88 & 0.02 & 0.59 & 0.17 & 0.10 & 0.70 & 0.40 & $<0.01$ \\
\hline
\end{tabular}

${ }^{\mathrm{a}}$ Qui = Quincy; Att = Attapulgas; StJ = St. Joseph; Suf = Suffolk; Bre = Brewton; Sto = Stoneville; Jac = Jackson; Cam = Camilla; Win = Winnsboro. Values represent mean seed cotton yield for the specified treatments. Differences (Diff) is the absolute difference between the least square mean values. Values and the maximum difference (Max Diff) of the best fungicide yield compared with the control is presented.

${ }^{b}$ Cultivar treatment with PHY499 = Phytogen $499 \mathrm{WRF}$ (more susceptible to target spot) and DPL1137 = Deltapine 1137 B2RF (more tolerant to target spot).

${ }^{c}$ Fungicide product active ingredients applied once or twice at each trial location; however, combined for presentation. NTC $=$ nontreated control; AZOX $=$ azoxystrobin (as Quadris); FLUT = flutriafol (as Topguard); PYRA = pyraclostrobin (as Headline); and PYRA + FLUX = pyraclostrobin + fluxapyroxad (as Priaxor). Max diff $=$ the maximum percent severity reduction compared with the NTC.

${ }^{\mathrm{d}}$ Fungicide application timing differed to where in 2014 the applications were made at first white flower (one application) with a second application made 14 days postapplication (two applications). Application timing in 2015 and 2016 occurred at first observation of target spot, followed by 14 days postapplication. Diff $=$ the absolute difference between the least square mean values. 
however, in some locations disease was not observed until more than 3 weeks after first bloom. Since the residual activity of the fungicides is expected to last between 14 and 21 days, disease occurring later in the season following a fungicide application made at first bloom would not be controlled. The late-season disease onset and defoliation observed at some locations were also less likely to impact yield. Cotton is indeterminate, but follows a definite flowering, fruiting, and yield accumulating pattern. Loss of canopy earlier during the flowering period will have a greater impact on yield than an equivalent loss of leaves later in the season when a greater percentage of the bolls will have been set and maturing. In the four site-years where fungicide treatments resulted in significant yield savings, disease onset occurred in late July and early August. Thus 70 to 90 days after planting, which often coincides with early flowering and row closure, is an important time to scout for target spot and to apply fungicide if disease is observed. The fungicide application timing approach in the
A
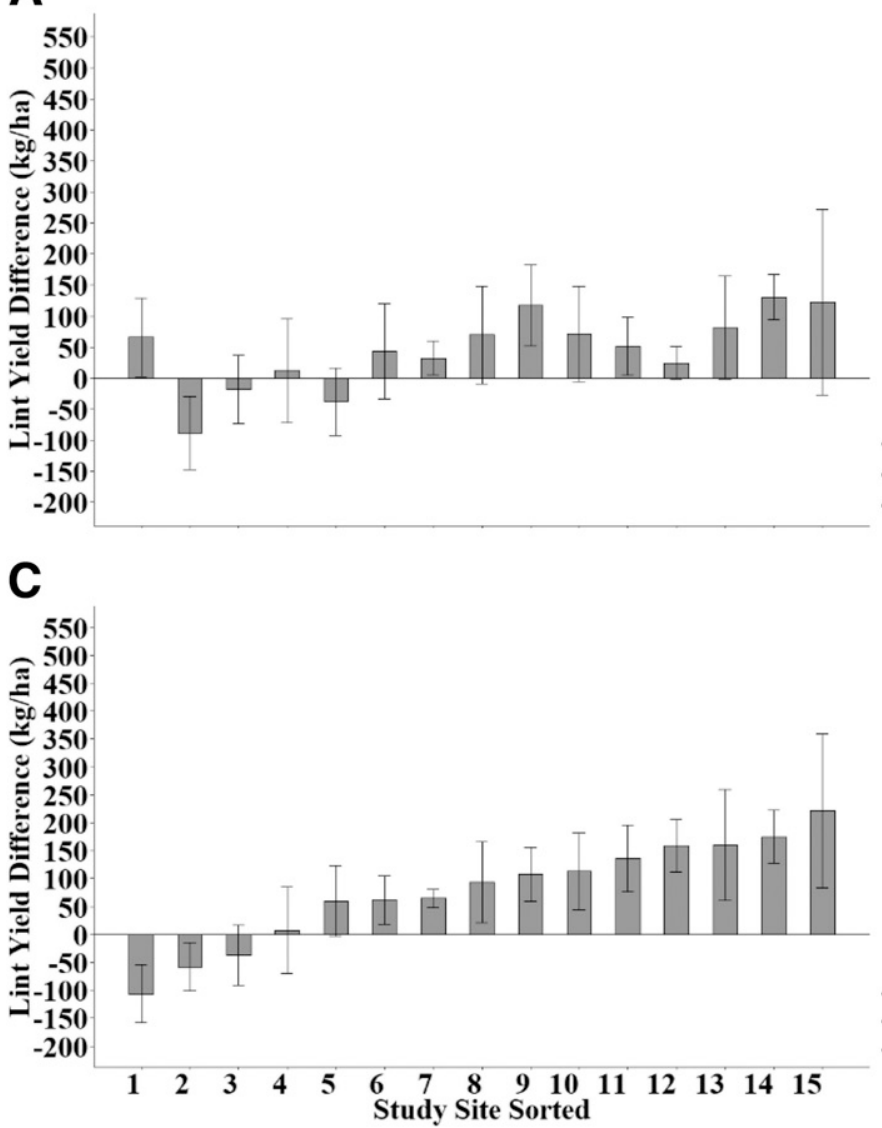

B

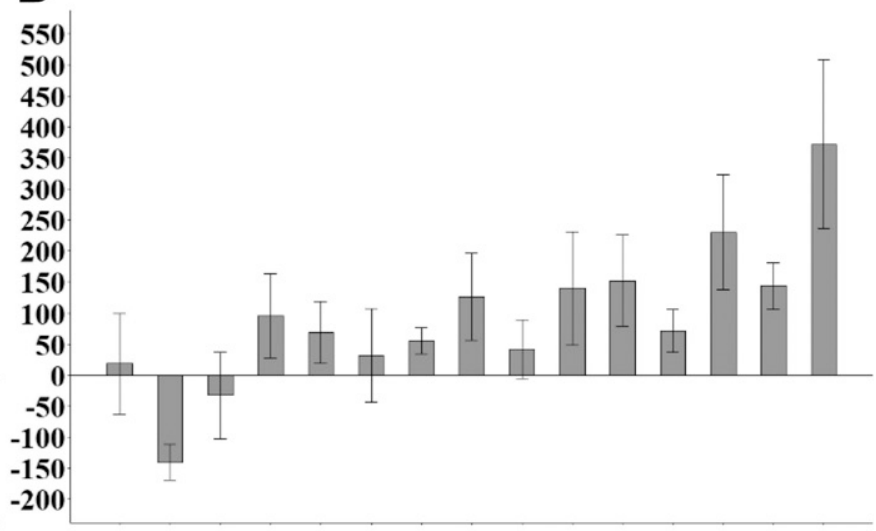

D

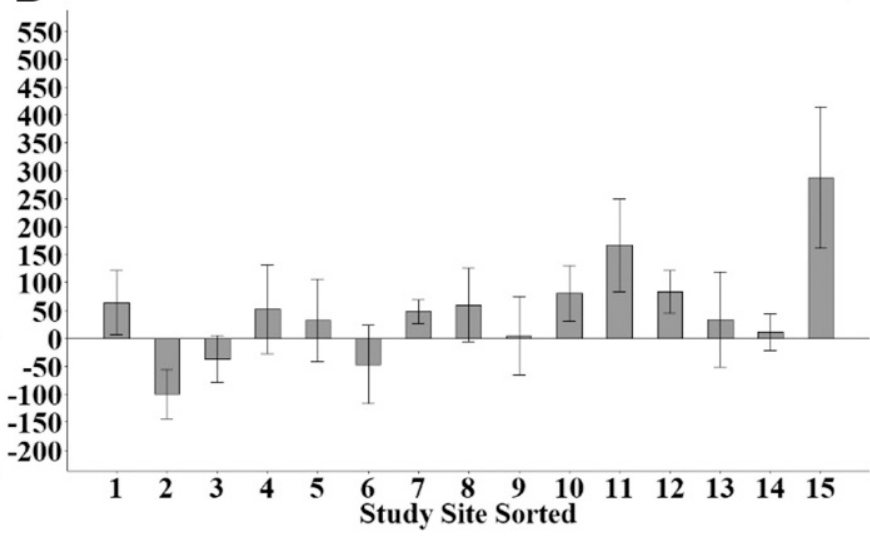

Fig. 1. Fungicide treatment lint yield differences (fungicide yield - respective control yield) from 15 locations conducted during 2014, 2015, and 2016. Fungicide treatments included A, azoxystrobin (Quadris), B, pyraclostrobin (Headline), C, pyraclostrobin + fluxapyroxad (Priaxor), and D, flutriafol (Topguard). Study sites were sorted from lowest to highest based on the pyraclostrobin + fluxapyroxad data. Error bars represent the standard error of the difference. Each bar represents summary data from two cultivars (Phytogen 499 WRF and Deltapine 1137 B2RF), two fungicide applications (1 or 2 applications), and four replications. Control = plots not treated with fungicide for each cultivar. Experimental locations were Quincy, FL; Attapulgas and Camilla, GA; St. Joseph and Winnsboro, LA; Suffolk, VA; Brewton, AL; Stoneville, MS; and Jackson, TN.

Table 6. Log response ratio (effect size) relative to the nontreated, percent defoliation, and corresponding statistics for the influence of cultivar on the efficacy of fungicides on cotton defoliation, based on a random effect multivariate meta-analysis

\begin{tabular}{|c|c|c|c|c|c|c|c|c|c|c|}
\hline \multirow[b]{2}{*}{ Fungicide $^{c}$} & \multirow[b]{2}{*}{ Cultivar $^{\text {d }}$} & \multirow[b]{2}{*}{$\mathbf{K}^{\mathbf{e}}$} & \multicolumn{5}{|c|}{ Effect size $^{\mathbf{a}}$} & \multicolumn{3}{|c|}{ Percent reduction $^{b}$} \\
\hline & & & $\mathbf{L}$ & $\operatorname{se}\left(\mathbf{L}^{(C)}\right)$ & $\mathbf{C I}_{\mathbf{L}}$ & $\mathbf{C I}_{\mathbf{U}}$ & $P$ & $\overline{\mathbf{I}}$ & $\mathbf{C I}_{\mathbf{L}}$ & $\mathbf{C I}_{\mathbf{U}}$ \\
\hline \multirow[t]{2}{*}{ AZOX } & DPL1137 & 15 & -0.127 & 0.061 & -0.247 & -0.007 & 0.038 & 11.9 & 21.9 & 0.7 \\
\hline & PHY499 & 15 & -0.091 & 0.037 & -0.164 & -0.019 & 0.014 & 8.7 & 15.1 & 1.9 \\
\hline \multirow[t]{2}{*}{ PYRA } & DPL1137 & 15 & -0.116 & 0.068 & -0.284 & 0.016 & 0.085 & 10.9 & 24.7 & -1.6 \\
\hline & PHY499 & 15 & -0.126 & 0.0512 & -0.226 & -0.026 & 0.014 & 11.8 & 20.2 & 2.6 \\
\hline \multirow[t]{2}{*}{ PYRA+FLUX } & DPL1137 & 15 & -0.203 & 0.103 & -0.404 & -0.002 & 0.048 & 18.4 & 33.2 & 0.2 \\
\hline & PHY499 & 15 & -0.292 & 0.086 & -0.460 & -0.125 & 0.001 & 25.3 & 36.9 & 11.7 \\
\hline \multirow[t]{2}{*}{ FLUT } & DPL1137 & 15 & -0.141 & 0.072 & -0.283 & 0.001 & 0.051 & 13.1 & 24.6 & -0.1 \\
\hline & PHY499 & 15 & -0.148 & 0.038 & -0.223 & -0.074 & 0.001 & 13.8 & 19.9 & 7.1 \\
\hline
\end{tabular}

${ }^{a} \mathrm{~L}=$ Mean log-transformed response ratio for each treatment mean relative to the check mean; $\operatorname{se}\left(\mathrm{L}^{(\mathrm{C})}\right)=$ standard error of $\mathrm{L} ;$ lower $\left(\mathrm{CI}_{\mathrm{L}}\right)$ and upper $\left(\mathrm{CI}_{\mathrm{U}}\right)$ limits of the $95 \%$ confidence interval around $\mathrm{L}$; and $P=$ probability value (significance level).

${ }^{\text {b }}$ Mean percent savings $(\overline{\mathrm{I}})$ and lower $\left(\mathrm{CI}_{\mathrm{L}}\right)$ and upper $\left(\mathrm{CI}_{\mathrm{U}}\right)$ limits of the $95 \%$ confidence interval for $\overline{\mathrm{I}}$ based on the confidence limits for $\mathrm{L}$.

${ }^{c}$ Active ingredient of each of the fungicide products applied once or twice in the trial; however, combined for presentation. NTC $=$ nontreated control; AZOX = azoxystrobin (Quadris); PYRA = pyraclostrobin (Headline); PYRA+FLUX = pyraclostrobin + fluxapyroxad (Priaxor); FLUT = flutriafol (Topguard).

${ }^{\mathrm{d}}$ Cultivar treatment with PHY499 = Phytogen 499 WRF (more susceptible to target spot) and DPL = Deltapine 1137 B2RF (more tolerant to target spot).

e Total number of studies used in each analysis. 
current research was similar to that described by Bowen et al. (2018), in which the suggested optimum time for disease management and subsequent yield protection was 1 to 3 weeks after first bloom. Information from this research could be used to replace calendar-based scheduling of fungicide application by cotton farmers and provide biologically based information to improve the utility of fungicide treatment based on appearance of the disease relative to the stage of crop development.

The results from the current study and that of Bowen et al. (2018) suggest that one versus two fungicide applications does not appear to vary in their impact on target spot and yield savings. However, Bowen et al. (2018) did report that greater yield savings could be attained with an increasing number of fungicide applications, especially from three to five times in a season. While increasing fungicide applications created a positive yield effect, their experiment did not address how one or two applications would have compared if such timings were adjusted to optimize application timings. Such limitations regarding in-depth information on timing are also true for our study. However, three or more sequential product applications is not suggested for fungicide resistance management and would be cost prohibitive considering estimated returns. Proper application timing is more likely to have an economic impact on disease control than increasing fungicide application number. More information is needed to address timing of application. Even with scouting, the proper timing can be important as an economic benefit of fungicide treatment could be lost with the narrow return margins indicated herein.

Currently, the main fungicides registered for target spot management in cotton represent two fungicide modes of action (MOA), the QoIs or the demethylation inhibitors (DMI; triazole). However, a third MOA is represented in the pyraclostrobin + fluxapyroxad as a succinate dehydrogenase inhibitor or SDHI. Such a limitation in available mechanisms of fungicide action is a concern with a pathogen that has a well-documented history of developing resistance to fungicides in other crops (Adkison et al. 2012; Clark et al. 2011; Ishii et al. 2007; MacKenzie et al. 2018). Of those two MOAs, only products representing either a stand-alone QoI or containing a QoI as one of the active ingredients provided an economic benefit in the current study. Fortunately, to date, resistance to the QoI class has not been detected in $C$. cassiicola isolates originating from cotton (Laurel 2018). However, recent studies indicate that within the southeastern United States, there is limited genetic diversity among $C$. cassiicola cotton isolates originating from different states (Shrestha et al. 2017; Sumabat et al. 2018a, 2018b). The lack of genetic diversity could indicate that the pathogen population has a limited number of alleles that might be selected for by fungicide exposure, thus fungicide applications may have little impact on the population's structure (McDonald 2004). However, as the fungal population becomes more diverse, it will be critical to continually adjust management strategies to avoid selection pressure from fungicides that could potentially result in the elimination of this critical management tool. In order to maintain sustainable management strategies, it will be important to continue to monitor $C$. cassiicola population dynamics and incorporate cultivars with target spot tolerance.

The hypothesized difference between the two cotton cultivars' susceptibility to target spot was observed in the current study. PHY499 tended to have greater target spot severity and defoliation than DPL1137. These results support previous reports that PHY499 is more susceptible to target spot compared with several other cultivars originating from Deltapine (Bowen et al. 2018; Hagan et al. 2013, 2018). However, disease occurred on both cultivars, and similar percent yield savings to fungicides were observed regardless of cultivar. Whether or not genetic differences in susceptibility to target spot exist within commercial cultivars, differences in canopy architecture among cultivars may contribute to observed differences in target spot susceptibility. A major phenotypic difference between PHY499 and DPL1137 is canopy architecture, with PHY499 exhibiting more vigorous growth compared with DPL1137. The current and previous studies have suggested that canopy architecture can impact microclimate. Tall, dense canopy growth favors humidity and target spot development in the cotton understory (Marois et al. 2004). Cotton canopy architecture is generally managed with applications of plant growth regulators, such as mepiquat chloride, to produce a more compact plant (Marois et al. 2004; Reddy et al. 1992; Siebert and Stewart 2006). Canopy architecture and plant growth habit likely contribute to disease development as well as additional factors that may confer innate cultivar susceptibility. Future studies should address the potential

Table 7. Log response ratio (effect size) relative to nontreated control, percent yield savings, and corresponding statistics for the influence of cultivar on the efficacy of fungicide on seed cotton and lint yield, based on a random effect multivariate meta-analysis

\begin{tabular}{|c|c|c|c|c|c|c|c|c|c|c|c|}
\hline \multirow[b]{2}{*}{ Response $^{c}$} & \multirow[b]{2}{*}{ Fungicide $^{d}$} & \multirow[b]{2}{*}{ Cultivar $^{\mathrm{e}}$} & \multirow[b]{2}{*}{$\mathbf{K}^{\mathbf{f}}$} & \multicolumn{5}{|c|}{ Effect size $^{\mathbf{a}}$} & \multicolumn{3}{|c|}{ Percent savings ${ }^{\mathbf{b}}$} \\
\hline & & & & $\mathbf{L}$ & $\operatorname{se}\left(\mathbf{L}^{(\mathbf{C})}\right)$ & $\mathbf{C I}_{\mathbf{L}}$ & $\mathbf{C \mathbf { I } _ { \mathbf { U } }}$ & $\boldsymbol{P}$ & $\overline{\mathbf{I}}$ & $\mathbf{C I}_{\mathbf{L}}$ & $\mathbf{C I}_{\mathbf{U}}$ \\
\hline \multirow[t]{8}{*}{ Seed cotton $(\mathrm{kg} / \mathrm{ha})$} & AZOX & DPL1137 & 15 & 0.036 & 0.020 & -0.003 & 0.075 & 0.067 & 3.7 & -0.3 & 7.8 \\
\hline & & PHY499 & 15 & 0.017 & 0.020 & -0.022 & 0.055 & 0.401 & 1.7 & -2.2 & 5.6 \\
\hline & PYRA & DPL1137 & 15 & 0.042 & 0.020 & 0.003 & 0.081 & 0.034 & 4.3 & 0.3 & 8.4 \\
\hline & & PHY499 & 15 & 0.051 & 0.019 & 0.013 & 0.089 & 0.008 & 5.2 & 1.3 & 9.3 \\
\hline & PYRA+FLUX & DPL1137 & 15 & 0.047 & 0.020 & 0.008 & 0.086 & 0.017 & 4.8 & 0.8 & 8.9 \\
\hline & & PHY499 & 15 & 0.059 & 0.022 & 0.015 & 0.102 & 0.011 & 6.1 & 1.5 & 10.7 \\
\hline & FLUT & DPL1137 & 15 & 0.029 & 0.020 & -0.011 & 0.068 & 0.153 & 2.9 & -1.1 & 7.0 \\
\hline & & PHY499 & 15 & 0.018 & 0.020 & -0.021 & 0.057 & 0.361 & 1.8 & -2.1 & 5.9 \\
\hline \multirow[t]{8}{*}{ Lint (kg/ha) } & AZOX & DPL1137 & 15 & 0.010 & 0.015 & -0.018 & 0.039 & 0.485 & 1.0 & -1.8 & 3.9 \\
\hline & & PHY499 & 15 & 0.010 & 0.020 & -0.029 & 0.049 & 0.604 & 1.0 & -2.9 & 5.0 \\
\hline & PYRA & DPL1137 & 15 & 0.048 & 0.018 & 0.014 & 0.083 & 0.006 & 4.9 & 1.4 & 8.6 \\
\hline & & PHY499 & 15 & 0.056 & 0.022 & 0.013 & 0.099 & 0.010 & 5.8 & 1.3 & 10.4 \\
\hline & PYRA+FLUX & DPL1137 & 15 & 0.034 & 0.014 & 0.006 & 0.062 & 0.017 & 3.5 & 0.6 & 6.4 \\
\hline & & PHY499 & 15 & 0.056 & 0.020 & 0.016 & 0.096 & 0.006 & 5.8 & 1.6 & 10.1 \\
\hline & FLUT & DPL1137 & 15 & 0.033 & 0.014 & 0.005 & 0.061 & 0.023 & 3.4 & 0.5 & 6.3 \\
\hline & & PHY499 & 15 & 0.031 & 0.023 & -0.015 & 0.077 & 0.182 & 3.1 & -1.5 & 8.0 \\
\hline
\end{tabular}

\footnotetext{
${ }^{\text {a }} \mathrm{L}=$ Mean log-transformed response ratio for each treatment mean relative to the check mean; se $\left(\mathrm{L}^{(\mathrm{C})}\right)=$ standard error of $\mathrm{L}$; lower $\left(\mathrm{CI}_{\mathrm{L}}\right)$ and upper $\left(\mathrm{CI} \mathrm{U}_{\mathrm{U}}\right)$ limits of the $95 \%$ confidence interval around $\mathrm{L}$; and $P=$ probability value (significance level).

${ }^{\text {b }}$ Mean percent savings $(\overline{\mathrm{I}})$ and lower $\left(\mathrm{CI}_{\mathrm{L}}\right)$ and upper $\left(\mathrm{CI}_{\mathrm{U}}\right)$ limits of the $95 \%$ confidence interval for $\overline{\mathrm{I}}$ based on the confidence limits for $\mathrm{L}$.

c Seed cotton $=$ harvested seed cotton yield, Lint $=(($ seed cotton yield - weight of seed $) \times$ gin turnout $(\%))$ based on measurements as conducted with a microgin from seed cotton samples.

d Active ingredient of each of the fungicide products applied once or twice in the trial; however, combined for presentation. NTC = nontreated control; AZOX $=$ azoxystrobin (Quadris); PYRA = pyraclostrobin (Headline); PYRA+FLUX = pyraclostrobin + fluxapyroxad (Priaxor); FLUT = flutriafol (Topguard).

e Cultivar treatment with PHY499 = Phytogen $499 \mathrm{WRF}$ and DPL = Deltapine 1137 B2RF.

${ }^{\mathrm{f}}$ Total number of studies used in each analysis.
} 
role of canopy architecture in target spot development and evaluate the effectiveness of aggressive canopy management with either earlier or more frequent applications of plant growth regulators as a tactic to reduce target spot severity.

The current regional study focused on developing best management practices for cotton target spot. Even though risk factors for predicting disease onset and development as well as yield losses need to be further characterized, the current study and others demonstrate the importance of integrated disease management, including cultivar selection and optimum application timing of an efficacious fungicide (Bowen et al. 2018; Hagan et al. 2018). Although cotton cultivars may inherently vary in overall susceptibility to target spot, the potential for percent yield losses was similar between the two cultivars evaluated. At this time, it is unlikely that cultivar selection alone can be relied on for management when target spot risk is high. Canopy architecture rather than innate susceptibility may be important in driving disease development since a dense canopy creates a microclimate favorable for infection and spread of $C$. cassiicola. Thus, management practices that minimize rank growth, such as following conservative recommendations for nitrogen fertility and the application of plant growth regulators, may be effective for reducing target spot severity (Gerik et al. 1998; Siebert and Stewart 2006). All fungicides evaluated in this study reduced target spot associated defoliation, but only pyraclostrobin and pyraclostrobin + fluxapyroxad consistently protected yield. Fungicide application timings relative to disease and crop development are critical to attaining positive economic returns. Thus, for several weeks following first bloom, the presence of the disease and/or occurrence of environmental conditions conducive to $C$. cassiicola cotton infections should be assessed before the decision is made to apply a fungicide. Fungicides can be a useful tool in target spot management; however, there is a narrow margin for positive economic returns on investment. Therefore, assessing risk will be critical to any successful management strategy.

\section{Acknowledgments}

We thank all of the technicians who assisted with establishment, maintenance, and harvest of field experiments.

\section{Literature Cited}

Adkison, H. M., Margenthaler, E., Burlacu, V., Willis, R., and Vallad, G. E. 2012. Occurrence of resistance to respiratory inhibitors in Corynespora cassiicola isolates from Florida tomatoes. Phytopathology 102:S4.2.

Bell, A. A. 1999. Diseases of cotton. Pages 553-593 in: Cotton: Origin, History, Technology, and Production. C. W. Smith and J. T. Cothren, eds. John Wiley \& Sons, Inc., New York, NY.

Bowen, K. L., Hagan, A. K., Pegues, M., Jones, J., and Miller, H. B. 2018. Epidemics and yield losses due to Corynespora cassiicola on cotton. Plant Dis. 102:2494-2499.

Butler, S., Young-Kelly, H., Raper, T., Cochran, A., and Jordan, J. 2016. First report of target spot caused by Corynespora cassiicola on cotton in Tennessee. Plant Dis. 100:535.

Clark, J. S., Blythe, E. K., Copes, W. E., Windham, A. S., Bost, S. C., and Windham, M. T. 2011. Growth sensitivity of Corynespora cassiicola to thiophanate-methyl, iprodione, and fludioxonil. Online. Plant Health Prog. 12:7.

Conner, K. N., Hagan, A. K., and Zhang, L. 2013. First report of Corynespora cassiicola-incited target spot on cotton in Alabama. Plant Dis. 97:1379.

Edmisten, K. 2012. Target leaf spot found in North Carolina cotton. Southeast Farm Press. 23 August 2012. Online publication. https://southeastfarmpress.com/ cotton/target-leaf-spot-found-north-carolina-cotton.

Faske, T. 2013. Cotton disease alert: A new foliar disease, Corynespora leaf spot, has been detected in Arkansas cotton. Arkansas Row Crops. 26 August 2013. Online publication. http://www.arkansas-crops.com/2013/08/26/cotton-diseasealert-corynespora-leaf-spot-has-been-detected-in-arkansas/

Fulmer, A. M., Walls, J. T., Dutta, B., Parkunan, V., Brock, J., and Kemerait, R. C., Jr. 2012. First report of target spot caused by Corynespora cassiicola on cotton in Georgia. Plant Dis. 96:1066.

Galbieri, R. D., Araújo, C. E. B., Kobayasti, L., Girotto, L., Matos, N. N., Marangoni, M. S., Almeida, W. P., and Mehta, Y. R. 2014. Corynespora leaf blight of cotton in Brazil and its management. Am. J. Plant Sci. 5:3805-3811.

Gerik, T. J., Oosterhuis, D. M., and Torbert, H. A. 1998. Managing cotton nitrogen supply. Adv. Agron. 64:115-147.

Hagan, A. K. 2014. Target spot management options in Alabama. Pages 45-48 in: 2014 Beltwide Cotton Conference Proceedings. http://www.Cotton.org/beltwide/ proceedings/2005-2016/index.htm.
Hagan, A. K., Bowen, K. L., Burch, K. B., and Miller, H. B. 2015. Fungicide inputs and control of target spot on seven cotton varieties in southwest Alabama, 2014. Plant Dis. Manage. Rep. 9:FC136.

Hagan, A. K., Bowen, K. L., Miller, B., and Nichols, R. L. 2018. Target spotincited defoliation and yields of selected cotton cultivars as influenced by fungicide inputs. Plant Health Prog. 19:156-162.

Hagan, A. K., Bowen, K. L., Miller, B., Scott, S., and Nichols, R. L. 2017. Fungicide selection and nozzle arrangement impact target spot control and yield of cotton. Plant Health Prog. 18:211-218.

Hagan, A. K., Campbell, H. L., Bowen, K. L., Pegues, M., and Jones, J. 2013. Reaction of mid- and full season flex cotton varieties to target spot in Alabama, 2012. Plant Dis. Manage. Rep. 7:FC006.

Harris, G. 1997. Potassium deficiency in cotton linked to leaf spot disease. Better Crops 81:10-11.

Hillocks, R. J. 1992. Fungal diseases of the leaf. Pages 191-238 in: Cotton Diseases. R. J. Hillocks, ed. CAB International, Wallingford, Oxon.

Hillocks, R. J., and Chinodya, R. 1989. The relationship between Alternaria leaf spot and potassium deficiency causing premature defoliation of cotton. Plant Pathol. 38:502-508.

Ishii, H., Yano, K., Date, H., Furuta, A., Sagehashi, Y., Yamaguchi, T., Sugiyama, T., Nishimura, K., and Hasama, W. 2007. Molecular characterization and diagnosis of QoI resistance in cucumber and eggplant fungal pathogens. Phytopathology 97:1458-1466.

Jones, J. P. 1961. A leaf spot of cotton caused by Corynespora cassiicola Phytopathology 51:305-308.

Jones, J. P., and Jones, J. B. 1984. Target spot of tomato: Epidemiology and control. Proc. Fla. State Hortic. Soc. 97:216-218.

Kandel, Y. R., McCarville, M. T., Adee, E. A., Bond, J. P., Chilvers, M. I., Conley, S. P., Kelly, H. M., Malvick, D. K., Mathew, F. M., Rupe, J. C., Sweets, L. E., Tenuta, A. U., Wise, K. A., and Mueller, D. S. 2018. Benefits and profitability of fluopyram-amended seed treatments for suppressing sudden death syndrome and protecting soybean yield: A metaanalysis. Plant Dis. 102:1093-1100.

Kandel, Y. R., Wise, K. A., Bradley, C. A., Tenuta, A. U., and Mueller, D. S. 2016. Effect of planting date, seed treatment, and cultivar on plant population, sudden death syndrome, and yield of soybean. Plant Dis. 100:1735-1743

Kirkpatrick, T. L., and Rothrock, C. S., eds. 2001. Compendium of Cotton Diseases, 2nd ed. American Phytopathological Society, St. Paul, MN.

Koenning, S. R., Creswell, T. C., Dunphy, E. J., Sikora, E. J., and Mueller, J. D. 2006. Increased occurrence of target spot of soybean caused by Corynespora cassiicola in the southeastern United States. Plant Dis. 90:974.

Laurel, M. K. S. 2018. Fungicide sensitivity of Corynespora cassiicola and assessment of management of target spot of cotton in Georgia. M.S. thesis. University of Georgia.

MacKenzie, K. J., Sumabat, L. G., Xavier, K. V., and Vallad, G. E. 2018. A review of Corynespora cassiicola and its increasing relevance to tomato in Florida. Plant Health Prog. 19:303-309.

Madden, L. V., and Paul, P. A. 2011. Meta-analysis for evidence synthesis in plant pathology: An overview. Phytopathology 101:16-30.

Marois, J. J., Wright, D. L., Wiatrak, P. J., and Vargas, M. A. 2004. Effect of row width and nitrogen on cotton morphology and canopy microclimate. Crop Sci. 44:870-877.

McDonald, B. A. 2004. Population genetics of plant pathogens. The Plant Health Instructor, https://doi.org/10.1094/PHI-A-2004-0524-01

Mehl, H. L., and Phipps, P. M. 2013. Applied Research on Field Crop Disease Control. Virginia Polytechnic Institute and State University, College of Agriculture and Life Sciences, Tidewater Agricultural Research \& Extension Center, Suffolk.

Pernezny, K., Stoffella, P., Collins, J., Carroll, A., and Beaney, A. 2002. Control of target spot of tomato with fungicides, systemic acquired resistance activators, and a biocontrol agent. Plant Prot. Sci. Prague 38:81-88.

Price, P., Singh, R., and Fromme, D. 2015. First report of target spot caused by Corynespora cassiicola in Louisiana cotton. Plant Health Prog. 16: 223-224.

Reddy, V. R., Trent, A., and Acock, B. 1992. Mepiquat chloride and irrigation versus cotton growth and development. Agron. J. 84:930-933.

Schultz, J., Bane, R., Roberts, J., Rhodes, A., Clark, J., and Westberg, D. 2017 Target spot epidemic in the north Delta: 2016, observations and key learnings. Page 242 in: Proc. Beltwide Cotton Conf. Natl. Cotton Counc. Am., Memphis, TN.

Sharma, N. 2017. Epidemiology of target spot of cotton and tomato. M.S. thesis. Auburn University

Shrestha, S. K., Lamour, K., and Young-Kelly, H. 2017. Genome sequences and SNP analyses of Corynespora cassiicola from cotton and soybean in the southeastern United States reveal limited diversity. PLoS One 12: $\mathrm{e} 0184908$.

Siebert, J. D., and Stewart, A. M. 2006. Influence of plant density on cotton response to mepiquat chloride application. Agron. J. 98:1634-1639.

Sumabat, L. G., Kemerait, R. C., Jr., and Brewer, M. T. 2018a. Phylogenetic diversity and host specialization of Corynespora cassiicola responsible for emerging target spot disease of cotton and other crops in the southeastern United States. Phytopathology 108:892-901. 
Sumabat, L. G., Kemerait, R. C., Jr., Kim, D. K., Mehta, Y. R., and Brewer, M. T. 2018b. Clonality and geographic structure of host-specialized populations of Corynespora cassiicola causing emerging target spot epidemics in the southeastern United States. PLoS One 13:e0205849.

Wei, Y.-X., Zhang, H., Pu, J.-J., and Liu, X.-M. 2014. First report of target spot of cotton caused by Corynespora cassiicola in China. Plant Dis. 98:1006.
Whitehead, A. 2002. Meta-analysis of Controlled Clinical Trials. John Wiley \& Sons, LTD, West Sussex, England.

Woodward, J. E., Dodds, D. M., Main, C. L., Barber, L. T., Boman, R. K.,

Whitaker, J. R., Edmisten, K. L., Banks, J. C., Buehring, N. W., and Allen, T. W. 2016. Evaluation of foliar applications of strobilurin fungicides in cotton across the Southern United States. J. Cotton Sci. 20:116-124. 